\begin{tabular}{|l|l|l||}
\hline \multicolumn{2}{|c|}{ PublisherInfo } \\
\hline \hline PublisherName & $:$ & BioMed Central \\
\hline \hline PublisherLocation & $:$ & London \\
\hline \hline PublisherImprintName & $:$ & BioMed Central \\
\hline \hline
\end{tabular}

\title{
Unstable angina pectoris
}

\begin{tabular}{|l|l|l||}
\hline \multicolumn{2}{|c|}{ ArticleInfo } \\
\hline \hline ArticleID & $:$ & 4190 \\
\hline \hline ArticleDOI & $:$ & $10.1186 /$ ccf-2000-4432 \\
\hline \hline ArticleCitationID & $:$ & 4432 \\
\hline \hline ArticleSequenceNumber & $:$ & 49 \\
\hline \hline ArticleCategory & $:$ & Paper Report \\
\hline \hline ArticleFirstPage & $:$ & 1 \\
\hline \hline ArticleLastPage & $:$ & 2 \\
\hline \hline & & RegistrationDate : 2000-2-22 \\
\hline ArticleHistory & $:$ & OnlineDate \\
\hline \hline ArticleCopyright & $:$ & Current Science Ltd2000-22 \\
\hline \hline ArticleGrants & $:$ & \\
\hline \hline ArticleContext & $:$ & 1305422 \\
\hline \hline
\end{tabular}




\section{Keywords}

Angina

\section{Comments}

This excellent review looks at the pathogenesis, medical management and revascularisation procedures involved in this coronary syndrome. The trials involving aspirin, ticlopidine, clopidogrel, platelet glycoprotein $\mathrm{IIb} / \mathrm{III}$ a receptor antagonists and antithrombin therapies in unstable angina are highlighted, and conventional medical therapies discussed (beta-blockers, nitrates and calcium-channel blockers). The changing attitudes regarding revascularisation procedures, with the advent of coronary stenting and glycoprotein IIb/IIIa receptor inhibition, are explored. In addition, investigations are summarised which stratify the risk of further coronary events and influence decisions on whether medical management can be safely continued, or whether angiography and myocardial revascularisation procedures are required.Finally a flow diagram of treatment strategies is presented which stratifies patients into low, intermediate and high risk groups.

\section{References}

1. Yeghiazarians Y, Braustein JB, Askari A, Stone PH: Unstable angina pectoris. New Engl J Med . 1999, 342: 101-114.

This PDF file was created after publication. 